\title{
Conjunctival autografting with sutures versus without sutures in pterygium surgery: a prospective comparative study
}

\author{
Kaur H. ${ }^{1}$, Kaur M. ${ }^{2 *}$, Maqbool B. ${ }^{3}$ \\ DOI: https://doi.org/10.17511/jooo.2020.i02.02
}

\footnotetext{
$\mathbf{1}$ Happy Kaur, Lecturer, Department of Ophthalmology, Government Medical College, Jammu, Jammu and Kashmir, India.

2* Manpreet Kaur, Junior Resident, Department of Ophthalmology, Government Medical College, Jammu, Jammu and Kashmir, India.

3 Babbar Maqbool, Assistant Surgeon, Department of Ophthalmology, Government Medical College, Jammu, Jammu and Kashmir, India.
}

Introduction: Pterygium is a degenerative condition of subconjunctival tissues that proliferates as vascularized granulation tissue to invade the cornea. Treatment modalities may be medical or surgical. Objectives: The outcome studied in both groups in terms of operative time, postoperative symptoms, overall graft success. Material and Method: Prospective, randomized, comparative study conducted on 50 patients over a period of one year in the upgraded Department of Ophthalmology at GMC Jammu. Group, I (25 eyes) underwent attachment of conjunctival autograft by 10-0 silk suture and group II (25 eyes) attachment done without sutures. Results: Mean operating time was less without sutures ( $p$-value $=0.0001$, highly significant), the severity of Postoperative symptoms was more with suture. Graft successfully attached in both groups. Conclusion: Present study concluded that both are effective methods but autograft without sutures associated with less operating time and less post-operative discomfort in terms of severity and duration

Keywords: Pterygium, Conjunctival autograft, Sutures

Corresponding Author

Manpreet Kaur, Junior Resident, Department of Ophthalmology, Government Medical College, Jammu, Jammu and Kashmir, India.

Email: sasanhaps@gmail.com
How to Cite this Article

Kaur H, Kaur M, Maqbool B. Conjunctival autografting with sutures versus without sutures in pterygium surgery: a prospective comparative study. Trop J Ophthalmol Otolaryngol. 2020;5(2):47-54. Available From

https://opthalmology.medresearch.in/index.php/jooo /article/view/122
To Browse

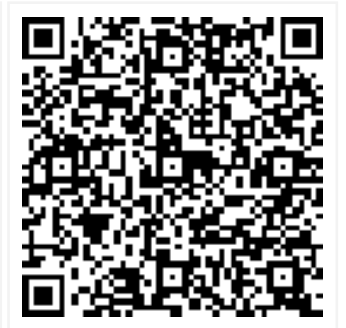

Manuscript Received 2019-12-28

Conflict of Interest No

Review Round 1
2020-01-08
Funding
Nil

(c) 2020 by Happy Kaur, Manpreet Kaur, Babbar Maqbool and Published by Siddharth Health Research and Social Welfare Society. This is an Open Access article licensed under a Creative Commons Attribution 4.0 International License https://creativecommons.org/licenses/by/4.0/ unported [CC BY 4.0]. 


\section{Introduction}

Pterygium are, type-I hypersensitivity reaction, Tcell mediated type-IV hypersensitivity responses [1] accelerated fibroblast proliferation [2] chronic inflammation [1] elastodysplasia and elastodystrophy [3], stem cell aplasia [4] p53 tumor suppressor gene overexpression in the epithelium of the pterygium coupled with the disruption of the normal process of apoptosis in the conjunctiva. However, the most widely accepted explanation implicates UV rays exposure as the major causative factor. Fuchs [5] stated the pathology of pterygium keeping in mind the degenerative basis of it. The main constituent is fibrillary connective tissue. Bowman's layer lying below the pterygium is destroyed and that is why cornea does not regain normal transparency after excision of pterygium.

Austin P (3) described a highly characteristic histological appearance of pterygium in which four features predominate.

01. Hyalinization of sub-epithelial tissue of substantia -propria

02. Diffuse or lobular collection of eosinophilic granular material and increased number of fibroblasts and other cells

03. An increased amount of thickened and tortuous fibers that stain strongly with elastin stains adjacent to or beneath the hyalinised region

04. Concretions within the hyalinised and granular areas that may show either eosinophilia or basophilia.

Clinically pterygium can be divided into four partsCap, head, neck and body. The Head is triangular in shape which is firmly adherent to the cornea. The body is the fan-shaped expansion from the neck, consisting of epithelium, connective tissue, and blood vessels. The clinical appearance of pterygium differs according to stage and degree of activity of process that leads to its formation [6]. In the active stage, it is hyperaemic with dilated and congested blood vessels with a halo of grayish-white opacity and looks thickened and opaque. In the atrophic stage, it is seen with the cicatrized look and with decreased engorgement of blood vessels, having no halo of opacity. Generally, it is asymptomatic except for cosmetic blemish. However, as it advances it may encroach the pupillary area causing a decrease in visual acuity. Large nasal pterygium may cause diplopia due to the limitation of abduction from the traction of the conjunctiva.
Moreover, it may disturb the corneal tear film leading to dryness and punctate keratitis with symptoms of irritation. Other symptoms include photophobia, tearing, foreign body sensation and corneal astigmatism.

Treatment modalities may be medical or surgical. From earliest times medical treatment has been tried and found unsatisfactory such as application of solid choline chloride, the topical use of steroids and subconjunctival injection of hyaluronidase. The report of surgical treatment of pterygium dates to or before 1000 B.C. Initially, excision with simple closure of the wound was done. Some thought it was crucial to cover the exposed peribulbar defect with normal conjunctiva. Some designed various rotating conjunctival flaps to accomplish this $[7,8,9]$.

Some favored the use of free graft. Some favored the use of bulbar conjunctiva to cover the defect from the same or opposite eyes $[10,11,12]$. The bare sclera technique described by $D^{\prime}$ Ombrain [13] has been practiced worldwide as the most basic and simple technique for pterygium removal. Pterygium surgery is marred by its high recurrence rate. Recurrence rate as high as $30 \%$ to $40 \%$ have been reported after excision of primary pterygium $[14,15,16,17,18,19]$.

The various other adjuncts have been used to reduce the recurrence rate. Kunitomo and Mori [20] reported the effect of postoperative use of mitomycin $-0.04 \%$ as eyedrops to prevent pterygium recurrence after excision but it was associated with the serious sight-threatening complication. It has been reported to cause superficial punctate keratitis [21], scleral ulceration and calcification, corneoscleral, ciliary body and vitreoretinal toxicity and uveitis and secondary glaucoma [22].

Conjunctival autografting after pterygium excision is associated with a lower recurrence rate of $2 \%-9 \%$ and relatively few sight-threatening complications. Conjunctival autografting is recognized as a procedure of choice for pterygium surgery. It involves obtaining a graft from superotemporal limbal conjunctiva in case of nasal pterygium and placing the graft over the bare sclera after pterygium excision. Stem cells from the limbal conjunctiva act as a barrier to the conjunctival cells migrating on to the corneal surface [23]. The current method of attaching conjunctival autograft is by means of suturing. 
The use of suture material is associated with several disadvantages, including prolonged operating time, postoperative discomfort and potential for suture related complications such as buttonhole, suture abscesses, granuloma formation, tissue necrosis, and giant papillary conjunctivitis. To prevent these complication ophthalmic surgeons are switching to sutureless surgery. A cross-sectional study also describes a successful outcome with a sutureless and glue-free conjunctival autograft. It also suggested that the opposition of the lids to the bulbar conjunctiva provides a natural biological dressing and confers a unique wound healing environment. The lids provide compression, a smooth frictional surface, avascular bed with immune capability in close proximity to the injury site [24]. Therefore this study was undertaken to compare the conjunctival autograft with and without sutures in terms of operating time, postoperative symptoms and graft success.

\section{Aims and objectives}

The outcome measures were studied in both groups in terms of Operative time, Postoperative symptoms and Overall graft success

\section{Material and Methods}

Setting: It was a Prospective, randomized, comparative study conducted on 50 patients over a period of one year from January 2017 to January 2018 in upgraded Department of Ophthalmology at GMC Jammu. Group, I consisted of 25 eyes who underwent attachment of conjunctival autograft by 10-0 nylon suture and in Group II (25 eyes) attachment was done without suture. In Group I, the graft was sutured with interrupted $10-0$ sutures and in Group II, no sutures applied.

Duration and Type of Study: This was a Prospective, Comparative Study conducted on 50 patients over a period of one year from January 2017 to January 2018.

Permission was taken from the institutional ethical committee. Written Informed consent was taken from all patients after explaining the examination, benefits, and risk of, surgical procedure.

Fifty patients were prospectively enrolled for pterygium surgery. Patients were randomly divided into two groups. Group, I consisted of 25 eyes who underwent attachment of conjunctival autograft by 10-0 nylon suture and Group II (25 eyes) attachment done without suture.
In Group I, the graft was sutured with interrupted 10-0 sutures and in Group II, no sutures applied

Inclusion Criteria: Patients in the age group of 20 to 70 years of either sex.

Exclusion Criteria: Recurrent pterygium, History of Ocular Pathology other than refraction resulting in decreased visual Acuity, Ocular surface disorders, History of ocular surgery or trauma in past and Glaucoma suspect.

Preoperative Assessment: Detail medical and ophthalmological history was taken, Uncorrected and Best-corrected visual acuity was recorded with Snellen's chart, Slit-lamp examination was done, Fundoscopy, NCT (Non-CONTACT tonometry), Keratometry, Haemoglobin, Bleeding Time, Clotting Time, Prothrombin Time, PTI and Fasting Blood Sugar were done. All Patients were explained regarding the procedure and informed consent was taken.

Operative Procedure: Topical antibiotics four times a day were given one day prior to surgery. The operative procedure was performed under local anesthesia. Topical xylocaine 4\% drops (at the interval of five mins ) four times before surgery was instilled. Peribulbar anesthesia with $5 \mathrm{ml}$ of $2 \%$ lignocaine and $0.5 \%$ Bupivacaine was given. After preparing and draping the selected eye, an eye speculum was inserted and eyelids were retracted. $0.5 \mathrm{ml}$ of $2 \%$ xylocaine was injected just underneath the body of pterygium with 26 gauge needle. Pterygium excision was done by the same surgeon in both groups with a similar technique. After holding the pterygium with fixation forceps a small incision was given in conjunctiva just medial to head of pterygium to separate conjunctiva from the body of the pterygium with west cott scissors. The pterygium was removed from the cornea by avulsion. Hemostasis was achieved spontaneously. The defect size was measured with a caliper. The size of the graft was measured with the caliper on superotemporal conjunctiva. $2 \%$ lignocaine was injected into conjunctiva to balloon the area and separate it from tenon's capsule. The graft was excised starting from fornical end reaching up to limbal area using forceps and Westcott scissors.

The graft was placed on the bare sclera in such a way so as to maintain the original orientation of the limbal border towards the cornea. The graft was smoothened at its bed taking care to avoid folding of the edges. 
Limbal side of the graft was affixed to the limbal area and sides of the graft were attached to surrounding conjunctiva with interrupted 10-0 sutures in Group-I (Conjunctival autograft with sutures). Antibiotic ointment was applied and pad and bandage did.

In Group -II (conjunctival autograft without sutures) The Limbal side of the graft was attached to the limbal side and sides of the graft to surrounding conjunctiva. Wait for 5-6 mins for the graft to adhere to the bare sclera as blood act as adhesive. No ointment is to be applied. The eye was patched and bandage. applied.

Postoperative Care- After removal of the pad and bandage topical antibiotic and steroid combination eye drops were given four times a day for 2 weeks then tapered over 4 weeks. Artificial tear drops were given four times a day for 6 weeks. sutures in Group -I were removed after 2 weeks

Follow up was done at

01. a) 1st postoperative day

02. b) 1st postoperative week

03. c) 1st postoperative month

04. d) 6th postoperative month

Data Analysis was done using the Chi-square test. A p-value $<0.05$ was considered as statistically significant.

\section{Results}

The present study was conducted on fifty patients attending the OPD of Govt. Medical College Jammu over a period of one year. The study was carried out to compare and evaluate the effectiveness of conjunctival autograft transplantation with and without sutures. Patients were divided into two groups of 25 patients each, Group-I consisted of 25 patients undergoing conjunctival autografting with sutures and in Group -II, conjunctival autograft was attached without sutures.

Of the 25 patients in Group I, 13 patients (52 \%) were males and 12 (48\%) were females. These patients were arranged in groups varying from 20 to 70 years. Their mean age was $41.37 \pm 11.75$ years and ranged from 25-62 years. Max's number of patients 17 (68\%) ranged from 20- 40 years. Of the 25 patients in Group II, 15 (60\%) were males and 10 were females. he age of patients in Group II ranged from 23-70 years and was arranged in groups varying 20-70 years.
The mean age of this population was $41.11 \pm 12.33$ years. Most of the patients $15(60 \%)$ were in the age group of 20-40 years (Table-1). Of the 25 patients in Group -I pterygium was present in the right eye in $9(36 \%)$ patients and in the left eye in $16(64 \%)$ patients. Of the 25 patients in Group -II, the pterygium was present in the right eye in 11 (44\%) patients and in the left eye in $14(56 \%)$ patients (Table-1).

Table-1: Pre-operative characteristics.

\begin{tabular}{|l|l|l|}
\hline \multicolumn{1}{|c|}{ Characteristics } & \multicolumn{1}{c|}{ Group-I } & \multicolumn{1}{c|}{ Group-II } \\
\hline No. of Eyes & 25 & 25 \\
\hline Age in years (Mean) & $41.37 \pm 11.75$ & $41.11 \pm 12.33$ \\
\hline Gender & 13 & \\
\hline Male & 12 & 15 \\
\hline Female & 12 & 10 \\
\hline Eye involved & & \\
\hline Right & 9 & 11 \\
\hline Left & 16 & 14 \\
\hline
\end{tabular}

Statistically, no significant difference was found in preoperative characteristics of pterygium between two groups

Table-2 -Operating time.

\begin{tabular}{|l|l|l|}
\hline & Group-I & Group-II \\
\hline Mean operating time (min) & 37.26 & 23.20 \\
\hline p-value-.0001 highly significant & & \\
\hline
\end{tabular}

In Group -I mean operating time was 37.76 min and in Group -II it was 23.20 min. p-value was .0001 value which is highly significant. Mean operating time in GROUP-II was less as compare to GROUP-I and was found to be statistically significant (Table2).

Table-3: Overall success rate.

\begin{tabular}{|l|l|l|}
\hline \multicolumn{1}{|c|}{ Success Rate } & \multicolumn{1}{|c|}{ Group-I } & \multicolumn{1}{c|}{ Group-II } \\
\hline Yes & 25 & 25 \\
\hline No & 0 & 0 \\
\hline
\end{tabular}

The overall success rate in both groups was similar (Table-3).

Postoperative symptoms - Subjective symptoms of pain, foreign body sensation, watering, and discomfort were fewer and disappeared rapidly in Group -II as compared to Group -I. The intensity of these symptoms was significantly lower in Group -II as compared to Group -I on all follow up days. All patients treated were asymptomatic by 2 weeks in Group -II and by 4 weeks in Group -I.

Table-4: Grading of pain/ discomfort and watering. 


\begin{tabular}{|l|l|l|}
\hline GRADE & \multicolumn{1}{|c|}{ Pain/Discomfort } & \multicolumn{1}{c|}{ Watering } \\
\hline 1 & No Pain & No watering \\
\hline 2 & Min Discomfort & Minimal watering \\
\hline 3 & Moderate with some discomfort & Moderate watering \\
\hline 4 & Severe /interfering with sleep & Severe watering \\
\hline
\end{tabular}

In the Group -I,12 patients had Grade-II discomfort, 10 patients complained of Grade-IIII discomfort and 3 patients had Grade-IV discomfort. In Group -II 20 patients had Grade -II discomfort and 5 patients had Grade-III discomfort. (Table 4 and 5).

Table-5: Grade based breakup of patients included in the study.

\begin{tabular}{|c|c|c|c|c|c|c|}
\hline Operating procedure & No of eyes & & Watering & stoperative & fort & Total \\
\hline Grade & & Grade-I & Grade-II & Grade-III & Grade-IV & \\
\hline Group-I & 25 & 0 & $12(48 \%)$ & $10(40 \%)$ & $3(12 \%)$ & $25(100 \%)$ \\
\hline Group-II & 25 & 0 & $20(80 \%)$ & $5(20 \%)$ & 0 & $25(100 \%)$ \\
\hline
\end{tabular}

Chi-square is $6.67 \mathrm{P}==.03$ significant

Table-6: Postoperative complication.

\begin{tabular}{|l|l|l|l|l|}
\hline & \multicolumn{1}{|c|}{ Group-I } & $\%$ & \multicolumn{1}{c|}{ Group-II } & $\%$ \\
\hline Conjunctival hyperemia & $20 / 25$ & $80 \%$ & $20 / 25$ & $80 \%$ \\
\hline Corneal defects & $5 / 25$ & $20 \%$ & $4 / 25$ & $0 \%$ \\
\hline Pyogenic granuloma & $0 / 25$ & $0 \%$ & $0 / 25$ & $0 \%$ \\
\hline Symblepharon & $0 / 25$ & $0 \%$ & $0 / 25$ & $0 \%$ \\
\hline Conjunctival granuloma & $1 / 25$ & $4 \%$ & $0 / 25$ & $0 \%$ \\
\hline Recurrence & $1 / 25$ & $4 \%$ & $0 / 25$ & $0 \%$ \\
\hline Increased IOP & $0 / 25$ & $0 \%$ & $0 / 25$ & $0 \%$ \\
\hline Others & $0 / 25$ & $0 \%$ & $0 / 25$ & $0 \%$ \\
\hline
\end{tabular}

Chi-square test was non-significant

In Group I Twenty patients had conjunctival hyperemia, five patients had corneal defects one patient had conjunctival granuloma. The recurrence of pterygium was observed in one patient at the end of the 2 nd postoperative month (Table-6).

In Group II, Twenty patients had conjunctival hyperemia and four patients had corneal defects. No other complication was observed in this group. In both the group's conjunctival hyperemia and corneal defects resolved after the 1st postoperative week with the use of topical lubricating and antibiotics drops. The conjunctival granuloma that was observed in one patient in Group I at the end of the 1st postoperative week was treated by surgical excision. (Table-6)

So, in the present study, it was concluded that Preoperative features between the two groups were statistically not significant. Mean operating time was less in the conjunctival autograft group without sutures ( $p$-value $=0.0001$, highly significant). The severity of Post-operative symptoms was more in the suture group. Graft successfully attached in both groups.

\section{Discussion}

The high rate of recurrence after pterygium excision has been the main obstacle in its successful treatment. However, in its endeavor to minimize recurrence different techniques with different adjuncts were tried by various authors from time to time. Although pterygium excision is considered to be a minor procedure, it is still challenging for ophthalmic surgeons worldwide. Pterygium surgery will be successful only when it prevents its recurrence. Although many surgical modalities have been proposed to treat pterygium, none of them is yet an ideal one to accomplish the desired end result. Adjunctive treatments in the form of betaradiations, argon laser photocoagulation, and thiotepa were introduced to reduce the rate of recurrence but none of them were without complications. The use of Mitomycin drops have also been used to prevent the recurrence of pterygium after its excision but mitomycin use is also associated with complication such as corneal scleral melting, cataract, uveitis, symblepharon, secondary glaucoma.

The bare sclera technique used for pterygium excision was also associated with a high recurrence rate. Kenyon et al [12] popularized the conjunctival autograft transplantation technique. It reestablishes the barrier function of the limbus and hence significantly lowers the recurrence rate. The conjunctival autograft is either attached with sutures, autologous blood or fibrin glue. Attaching conjunctival autograft using autologous blood also known as suture and glue-free graft technique. Although conjunctival autografting is an effective method for the prevention of recurrence after pterygium surgery, suturing needs surgical experience and technical skills. 
Sutures also lead to patient discomfort, symblepharon or graft rupture. Suzuki et al reported that silk and nylon sutures may cause conjunctival inflammation and Langerhans cell migration into the cornea [25]. Mitra et al's study conducted a study in which 19 patients underwent graft fixation without sutures [26]. The mean surgical time was $11 \mathrm{~min}$, no graft was lost and none of the pterygium recurred during 6 months follow up. The present study was carried out to compare pterygium excision with the attachment of conjunctival graft with sutures versus without sutures. The results were compared in terms of operative time, postoperative symptoms and overall graft success.

In the present study in Group, I mean operating time was $37.76 \mathrm{~min}$ and in Group -II it was 23.20 min. p-value was 0001 value which is highly significant. Karazeli.et al reported an operating time of 32.5 mins in the case of a suture group and 15.7 mins in the case of the fibrin glue group [27]. Mitra et al reported a mean surgical time of $11 \mathrm{~min}$ in case of conjunctival autograft without sutures [26]. In the present study, postoperative symptoms were less severe with conjunctival autograft without sutures than with sutures similar to Uy et al study [28]. Malik K P et al and Wit D et al, also reported that postoperative symptoms were more with suture group than with sutureless group [23, 24].

In the present study, the graft was attached in both groups with three out of twenty-five in the suture group and two out of twenty-five in the suture-free group had graft edema which resolved over 1st post-operative week. Corneal defects were observed in five out of twenty-five in the suture group and four out of twenty-five in the suture-free group. One patient had conjunctival granuloma and one patient had a recurrence in the suture group. Chi-square was non-significant. In a study conducted by Elvan S [29], postoperative conjunctival edema occurred in eight eyes, recurrence in 3 eyes and none had granuloma formation. The follow-up period was six months and recurrence occurred at four months. A study by Malik K P et al [23] reported a recurrence rate of $2.5 \%$ and no granuloma formation at 6 months of follow up in case of sutureless conjunctival autografting.

Hall R C et al [30] reported no recurrence in conjunctival autografting with glue and two cases of recurrences in the suture group. Wit D et al [24] reported no recurrence in 15 eyes in both conjunctival autografting with and without sutures at follow up period of nine months In Sharma et al
S [31] study out of 150 patients who underwent graft fixation with autologous blood recurrence during follow up period was seen in 4 patients. In the present study, no recurrence was noted in the suture-free group as compared to one case in the suture group. Operating time for the suture group was more in a present study similar to Harvey et al, Karazeli et al, Bahar et al studies [32,27,33]. In the present study, postoperative symptoms were less severe with conjunctival autograft without sutures than with sutures similar to UY et al and Bahar et al study [28,33]. The graft was successfully attached in both groups in the present study. Similarly, grafts were successfully attached in both groups and intact after 2 months in UY et al study [28].

\section{Conclusion}

The present study concluded that both are effective methods of conjunctival autograft but autograft without sutures associated with less operating time, less learning curve and less post-operative discomfort in terms of severity and duration.

\section{What does the study add to the existing knowledge?}

This study was conducted to compare methods of conjunctival autografting with and without sutures, There are other methods of attaching conjunctival autograft without sutures like fibrin glue. But fibrin glue is costly and the risk of infection transmission is there.

The surgical treatment of pterygium with conjunctival autograft without sutures i.e. sutureless and glueless, is a very effective and easy technique with minimum surgical time, better postoperative comfort to the patient and very low recurrence rate. It is also cost-effective as compared to sutures and other sutureless techniques like fibrin glue. In recent times hope it becomes the gold standard treatment of pterygium excision with conjunctival autograft. As still conventional methods of pterygium excision are practiced widely.

\section{Author's contribution}

Manuscript preparation was jointly done by all authors. The surgical procedure was done by $\mathbf{D r}$. Happy Kaur. Postoperative follow up was done jointly by all authors. Data analysis was done by $\mathbf{D r}$. Babar and Dr. Manpreet. 


\section{Reference}

01. Hill JC, Maske R. Pathogenesis of pterygium. Eye. 1989;3(Pt 2)218-226. doi: 10.1038/eye. 1989.31 [Crossref][PubMed][Google Scholar]

02. Cameron ME. History of pterygium- an electron microscopic study. Br J Ophthalmol. 1983;67(9)604608. doi: 10.1136\%2Fbjo.67.9.604 [Crossref] [PubMed][Google Scholar]

03. Austin $\mathrm{P}$, Jakobire $\mathrm{FA}$, Iwamoto $\mathrm{T}$. Elastodysplasia and elastodystrophy as the pathologic basis of pterygia and pingecula. Ophthalmol. 1998:90(1)96-109. doi: 10.1016/s0161-6420(83)34594-2

[Crossref] [PubMed][Google Scholar]

04. Tseng SCG. Concept and application of limbal stem cells. Eye. 1989;3(2)141-157. doi: 10.1038/ eye.1989.22 [Crossref][PubMed][Google Scholar]

05. Fuchs' E. Ueber das Pterygium- Graefes Arch. Ophthalmol. 1892;38;1. [Crossref][PubMed][Google Scholar]

06. Kamel S. Pterygium- Its nature and a new line of treatment. $\mathrm{Br}$ J Opthalmol. 1946;30;549-563. [Crossref][PubMed][Google Scholar]

07. Campodonico E. A new procedure in the excision method of pterygium operations. Tr Internat Cong Ophth Washington. 1922;12;201-204. [Crossref] [PubMed][Google Scholar]

08. Bangerter A. Pterygium operation and covering of conjunctival defects. Ophthalmologica. 1943;106;316. [Crossref][PubMed][Google Scholar]

09. Aratoon V. Surgery of the pterygium by conjunctival pedicle flap. Am J Opthalmol. 1697:63(6)1778-1779. doi: 10.1016/00029394(67)93665-3 [Crossref][PubMed][Google Scholar]

10. Elsching $\mathrm{H}$. $\mathrm{H}$ - Operation for relapsing pterygium. Klin Monatsbl F Augenh. 1926;76;714. [Crossref][PubMed][Google Scholar]

11. Gomez-Maruez J. New Operative Procedure for Pterygium. Arch De oftal hispano-am. 1931;32-87. [Crossref][PubMed][Google Scholar]

12. Kenyon KR, Wagoner MD, Hettinger ME. Conjunctival autograft transplantation for advanced and recurrent pterygium. Ophthalmol. 1985;92 (11)1461-1470. doi: 10.1016/s0161-6420 (85)33831-9 [Crossref][PubMed][Google Scholar]
13. $D^{\prime}$ Ombrain $A$. The surgical treatment of pterygium. $\mathrm{Br}$ J Opthalmol. 1948;32(2)65-71. doi: 10.1136\%2Fbjo.32.2.65 [Crossref][PubMed][Google Scholar]

14. Bernstein M, Unger SM. Experience with surgery and Strontium 90 in the treatment of pterygium. Am J Ophthalmol. 1960;49(5)1024-1029. doi: 10.1016/0002-9394(60)91828-6

[Crossref] [PubMed][Google Scholar]

15. Liddy B St L, Morgan JF. Triethylene thiophosphoramide (thiotepa) and pterygium. Am J Ophthalmol. $1966 ; 61(5$ Pt 1)888-890. doi: 10.1016/0002-9394(66)90931-7 [Crossref] [PubMed][Google Scholar]

16. Zauberman H. Pterygium and its recurence. Am J Ophthalmol. 1967;63(6)1780-1786. doi: 10.1016/0002-9394(67)93666-5 [Crossref] [PubMed][Google Scholar]

17. Youngson RM. Recurrence of pterygium after excision. Br J Ophthalmol. 1972;56(2)120-125. doi: 10.1136/bjo.56.2.120 [Crossref][PubMed][Google Scholar]

18. Singh $G$ and Rana RK. Evaluation of new polishing technique in surgery of primary pterygium. Ind J Ophthalmol. 1982;30(4)281-284. Available from: [Article][Crossref][PubMed][Google Scholar]

19. Anthrayose CV, Meinz N, Mani EJ. Selection of surgical technique and supportive treatment for the management of primary pterygium, Proc 54th Annual Conference, AIOS in Pasricha JK ed. Indian J Ophthalmology. 1996(Yearbook)272-273. [Crossref] [PubMed][Google Scholar]

20. Kunitomo N. Studies on the pterygium, Part 4- A treatment of the pterygium by mitomycin- $C$ instillation. Acta Soc Ophthalmol Jpn. 1963;67;601607. [Crossref][PubMed][Google Scholar]

21. Mastropasqua L, Carpineto $P$, Ciancaglini $M$, Gallenga PE. Long term results of intraoperative mitomycin $C$ in the treatment of recurrent pterygium. Brit J Ophthalmol. 1996;80(4)288-291. doi: 10.1136/bjo.80.4.288 [Crossref][PubMed] [Google Scholar]

22. Cardillo JA, Alves MR, Ambrosio LE, Poterio MB, Jose NK. Single intraoperative application versus postoperative mitomycin $\mathrm{C}$ eye drops in pterygium surgery. Ophthalmol. 1995;102(12)1949-1952. doi: 10.1016/s0161-6420(95)30770-1

[Crossref] [PubMed][Google Scholar] 
23. Malik KP, Goel R, Gupta A, Gupta SK, Kamal S, Malik VK, Singh S. Efficacy of sutureless and glue free limbal conjunctival autograft for primary pterygium surgery. Nepal J Ophthalmol. 2012;4(2)230-235. doi: 10.3126/nepjoph.v4i2.6537 [Crossref][PubMed][Google Scholar]

24. Wit D, Athanasiadis I, Sharma A, Moore J. Sutureless and glueless free conjunctival autograft in pterygium surgery- A case series. Eye. 2010:24(9)1474-1477. doi: 10.1038/eye.2010.75 [Crossref][PubMed][Google Scholar]

25. Suzuki T, Sano Y, Kinoshita S. Conjunctival inflammation induces Langerhans cell migration into the cornea. Curr Eye Res. 2000;21(1)550-553. [Crossref][PubMed][Google Scholar]

26. Mitra S. Autoblood as tissue adhesive for conjunctival autograft fixation in pterygium surgery. External Diseases Free Papers. 2011;562. [Crossref] [PubMed][Google Scholar]

27. Karalezli A, Kucukerdonmez C, Akova YA, AltanYaycioglu R, Borazan M. Fibrin glue versus sutures for conjunctival autografting in pterygium surgery- a prospective comparative study. Brit J Ophthalmol. 2008;92(9)1206-1210.

doi:

10.1136/bjo.2008.139600 [Crossref][PubMed] [Google Scholar]

28. Yüksel B, Ūnsal SK, Onat S. Comparison of fibrin glue and suture technique in pterygium surgery performed with limbal autograft. Int J Ophthalmol. 2010;3(4)316. [Crossref][PubMed][Google Scholar]
29. Elwan S. Comparison between suture less and glue free versus sutured limbal conjunctival autograft in primary pterygium surgery. Saudi J Ophthalmol. 2014;28(4)292-298. doi: 10.1016\%2Fj.sjopt.2014.03.012 [Crossref] [PubMed][Google Scholar]

30. Hall RC, Logan A J, Wells A P. Comparison of fibrin glue with sutures for pterygium excision surgery with conjunctival autografts. Clin Exp Ophthalmol. 2009;37(6)584-589. doi: 10.1111/j.1442-9071.2009.02105.x [Crossref] [PubMed][Google Scholar]

31. Sharma A, Moore J. Autologous fibrin glue for pterygium surgery with conjunctival autograft. Cont Lens Anterior Eye. 2009;32(5)209. doi: 10.1016/j.clae.2009.05.005 [Crossref][PubMed] [Google Scholar]

32. Uy HS, Reyes JM, Flores JD, Lim-Bon-Siong R. Comparison of fibrin glue and sutures for attaching conjunctival autografts after pterygium excision. Ophthalmol. 2005;112(4)667-671. doi: 10.1016/j.ophtha.2004.08.028 [Crossref][PubMed] [Google Scholar]

33. Bahar I, Weinberger D, Gaton DD, Avisar R. Fibrin glue versus vicryl sutures for primary conjunctival closure in pterygium surgery- longterm results. Curr Eye Res. 2007;32(5)399-405. doi: 10.1080/02713680701294723 [Crossref] [PubMed][Google Scholar] 